\title{
Thermal Microscopy Standards for Pharmaceutical Applications
}

\author{
R. A. Carlton, K. B. Roberts-Skilton \\ GlaxoSmithKline, King of Prussia, PA 19406
}

Thermal microscopy is used extensively in pharmaceutical science for the study of the solid-state form of new chemical entities [1,2]. The solid-state form of pharmaceuticals has a direct impact on the function and manufacture of pharmaceutical products. Thermal microscopy is applied to the discovery of new forms and to the elucidation of thermodynamic and kinetic form relationships. Thermal microscopy is typically one aspect of a complete thermal study involving differential scanning calorimetry, thermal gravimetric analysis, variable temperature and humidity $\mathrm{x}$-ray powder diffraction and vibrational spectroscopy.

Thermal microscopy can be defined as observations of materials as they are heated or cooled. Thermal microscopes vary from simple metal coated glass slides with limited control to dedicated stages with fine control of temperature and heat dissipation. Almost any optical microscope and many SEMs can be adapted for thermal observations. All thermal microscopes, however, require calibration and performance standards. Thermal calibration standards for pharmaceutical applications need to span a range of temperatures from approximately 50 to $300^{\circ} \mathrm{C}$. The calibration standard should melt over a narrow temperature range $\left(1-2^{\circ} \mathrm{C}\right)$, should have high purity, and should not completely sublime before melt. Ideally, the standard should readily recrystallize to facilitate determination of the equilibrium melting point. Thermal performance standards should span a similar temperature range as the calibration standards and should have high purity, but they should also exhibit typical thermal phenomena such as solid-solid transformations, solid-liquid-solid transformations, and sublimation. Performance standards that exhibit ready recrystallization from the melt and form transitions on cooling are also useful. The purpose of these performance standards is the assurance of the proper operation of the thermal microscope. These performance standards can also be used for training and instruction.

Table 1 presents 13 materials that have been recommended as melting point standards for general use with any melting point instrument and those specifically recommended for thermal microscopy are marked by an asterisk [3]. For many modern thermal stages it is possible to calibrate the control device using one known standard that melts at a relatively high temperature. The software adjusts data according to a linear calibration line drawn between the standard temperature and zero. Phenolphthalein is good material for a single point calibration since it has only limited sublimation and a relatively sharp melting point at $\sim 262^{\circ} \mathrm{C}$. Some thermal stage control devices do not allow for direct calibration and it is necessary to test a range of materials and develop a linear relationship between observed and standard melting point. Azobenzene $\left(68^{\circ} \mathrm{C}\right)$, acetanilide $\left(115^{\circ} \mathrm{C}\right)$, Salophen $\left(191{ }^{\circ} \mathrm{C}\right)$, and phenolphthalein $\left(26{ }^{\circ} \mathrm{C}\right)$ are acceptable standards for calibration lines.

Although many of the recommended standards are adequate for calibration and performance verification, other materials have some distinct advantages and should be considered. One example is L-tartaric acid which melts at $\sim 171^{\circ} \mathrm{C}$ with limited sublimation. D-mannitol is another possible standard (M.P $-166^{\circ} \mathrm{C}$ ) even though it has at least 3 known polymorphs. Additional standards will be recommended. 


\section{REFERENCES}

[1] M. Kuhnert-Brandstatter M, Thermomicroscopy in the Analysis of Pharmaceuticals, Pergamon Press, Oxford, 1971.

[2] I.M. Vitez, A.W. Newman, AW, Thermal Microscopy. In: Craig D, Reading M(ed) Thermal Analysis of Pharmaceuticals, CRC Press, Boca Raton, pp 221-264, 2007.

[3] H. Bervenmark et al., Bul. Wld Hlth Org. 28 (1963) 175-188.

TABLE 1. Standards for Thermal Microscopy Calibration and Performance Verification

\begin{tabular}{|c|c|c|}
\hline Standard & Melt Range, ${ }^{\circ} \mathrm{C}$ & Observations on Heating \\
\hline Azobenzene * & $66-69$ & $\begin{array}{l}\text { Liquid and solid sublimation, sharp melt, rapid } \\
\text { recrystallization }\end{array}$ \\
\hline Vanillin & $81-83$ & $\begin{array}{l}\text { Liquid and solid sublimation, sharp melt, slow } \\
\text { recyrstallization }\end{array}$ \\
\hline Benzil * & $94-96$ & $\begin{array}{c}\text { Extensive liquid sublimation, sharp melt, slow } \\
\text { recyrstallization }\end{array}$ \\
\hline Acetanilide * & $113-116$ & $\begin{array}{l}\text { Liquid, solid sublimation } \sim 90^{\circ} \mathrm{C} \text {, sharp melt, } \\
\text { rapid recrystallization }\end{array}$ \\
\hline Phenacetin * & $134-136$ & $\begin{array}{l}\text { Liquid, solid sublimation } \sim 120^{\circ} \mathrm{C} \text {, slow melt, } \\
\text { rapid recrystallization }\end{array}$ \\
\hline Benzanilide * & $163-167$ & $\begin{array}{c}\text { Complete solid sublimation from } 110-135 \\
{ }^{\circ} \mathrm{C} \text {, sharp melt of sublimate, rapid } \\
\text { recrystallization }\end{array}$ \\
\hline Sulfanilamide & $163-168$ & $\begin{array}{l}\text { Form change } \sim 135^{\circ} \mathrm{C} \text { followed by liquid and } \\
\text { solid sublimation, growth of new form during } \\
\text { melt, rapid recrystallization }\end{array}$ \\
\hline Salophen * & $188-191$ & $\begin{array}{c}\text { Form change } \sim 100^{\circ} \mathrm{C} \text {, liquid and solid } \\
\text { sublimation } \sim 150{ }^{\circ} \mathrm{C} \text {, sharp melt, rapid } \\
\text { recrystallization }\end{array}$ \\
\hline Sulfapyridine & $190-193$ & $\begin{array}{c}\text { Liquid sublimation } \sim 185^{\circ} \mathrm{C} \text {, sharp melt, slow } \\
\text { recrystallization }\end{array}$ \\
\hline Dicyandiamide * & $208-210$ & $\begin{array}{c}\text { Liquid sublimation } \sim 200^{\circ} \mathrm{C} \text {, form change near } \\
\text { M.P. followed by sharp melt, rapid } \\
\text { recyrstallization }\end{array}$ \\
\hline Saccharin * & $226-229$ & $\begin{array}{c}\text { Complete solid sublimation } 179-212{ }^{\circ} \mathrm{C}, \\
\text { form change } \sim 225^{\circ} \mathrm{C} \text {, sharp melt of sublimate, } \\
\text { rapid recyrstallization }\end{array}$ \\
\hline Caffeine & $234-239$ & $\begin{array}{c}\text { Complete solid sublimation } 110-135^{\circ} \mathrm{C} \text {, } \\
\text { sharp melt of sublimate, rapid recrystallization }\end{array}$ \\
\hline Phenolphthalein * & $258-263$ & $\begin{array}{c}\text { Form change } \sim 100^{\circ} \mathrm{C}, \text { limited sublimation, } \\
\text { sharp melt, slow recrystallization }\end{array}$ \\
\hline
\end{tabular}

* Specifically recommended for Thermal Microscopy [3] 